\title{
Physiotherapy Rehabilitation of Post-Hysterectomy Geriatric Patient: A Case Report
}

\author{
Madhura Darware ${ }^{1}$, Dhanashri Ghordadekar ${ }^{1}$, Renuka Dhole ${ }^{1}$ and Obaid Noman ${ }^{4}$ \\ ${ }^{1}$ Intern, Ravi Nair Physiotherapy College, Datta Meghe Institute of \\ Medical Sciences, Wardha, Maharashtra, India \\ ${ }^{2}$ Department of Pathology, Jawaharlal Nehru Medical College, Datta \\ Meghe Institute of Medical Sciences, Sawangi Meghe, Wardha \\ Corresponding author email: ghordadekardhanashri@gmail.com
}

\section{ABSTRACT}

Total abdominal hysterectomy is the removal uterus and the cervix.Most hysterectomies are performed in order to treat conditions such as fibroids, endometriosis, adenomyosis, prolapse of the pelvic organ and cancer. Following surgery, early mobilization is necessary and patient needs to be encouraged to get out of bed after surgery, which will help avoid chest problems and improve circulation. Immediately after operation and exercises, gentle leg and breathing exercises are important for recovery. A 62 years old female who had undergone total abdominal hysterectomy was referred for physiotherapist call. Patient complained of pain in lower abdomen and difficulty in mobility post operatively. Apart from medicinal intervention, physiotherapy wasgiven for six days a week along with pain management activities, respiratory exercises and home exercise program for 6 weeks. A comprehensive rehabilitation plan including home exercise regimen can help in early recovery and restoration of daily activities rapidly.

KEY WORDS: TOTAL HYSTERECTOMY, PHYSIOTHERAPY REHABILITATION, POST-OPERATIVE, BREATHING EXERCISES, HOME EXERCISE PROGRAMME.

\section{INTRODUCTION}

A hysterectomy is a surgical removal of uterus and also the cervix (neck of the womb). Total abdominal hysterectomy is the removal uterus and the cervix. (Internet source, 2020a) Most hysterectomies are performed in order to treat conditions such as fibroids, endometriosis, adenomyosis, prolapse of the pelvic organ and cancer( Internet source, 2020b). Following surgery, early mobilization is necessary and patient will be encouraged to get out of bed the after surgery, which will help avoid chest problems and improve circulation. Immediately after operation and exercises, gentle leg and

Biosc Biotech Res Comm P-ISSN: 0974-6455 E-ISSN: 2321-4007

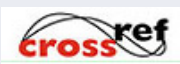

Identifiers and Pagination

Year: 2021 Vol: 14 No (6) Special Issue

Pages: 71-76

This is an open access article under Creative

Commons License Attribn 4.0 Intl (CC-BY).

DOI: $h t t p: / / d x$.doi.org/10.21786/bbrc/14.6.17 breathing exercises are important for recovery (Internet source, 2016). Preoperative physiotherapy measures and early advice is important .Surgery-related anaesthetics and bed rest can also affect lung function. In order to obtain the best outcomes from surgery and reduce the risk of complications, it is important to optimize lung function and health prior to surgery. Preoperative steps include: fitness maintenance by walking regularly, deep breathing exercises, huffing and coughing, striving for up to 30 minutes a day which will help remove any secretions after surgery (Internet source, 2020b).

Physiotherapy helps to promote surgical recovery by avoiding or remediating post-operative complications and delivering physical rehabilitation to support the return to premorbid physical function, and physiotherapy may have an effect on a variety of other domains though mainly concentrating on physical rehabilitation. Early mobilisation and pulmonary physiotherapy methods include physiotherapy procedures following major surgery. Deep breathing and coughing exercises, positive expiratory pressure systems, incentive spirometry, and

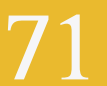


non-invasive ventilation are part of respiratory therapy (Sullivan et al., 2016).

Patient Information: This case involves a 62 years female who was housewife, built was endomorphic and hand of dominance was right. The patient undergone total abdominal hysterectomy on 24-10-19.Post operatively the complaints were pain at the lower abdomen which was the site of incision and the pain was burning and constricting in nature aggravates on coughing and during mobility and relieves in supine lying position. On NPRS patient rated 6/10.Patient also complaints of difficulty in bed mobility which was secondary to incisional pain and the patient was not able to adapt side lying position.

Patient had complaints of multiple fibroids in uterus and heavy menses with severe abdominal pain and heavy bleeding lasting for 20 days and for this reason sonography was done and fibroids were detected and was operated 3 years back for same reason. Then 6 months back she again started experiencing heavy bleeding with clots ,pain and weakness she took medicine but their was no relief so she came to hospital where fibroids was seen in sonography and for this reason surgery was performed. There was no history diabetes, tuberculosis, bronchial asthma, hypertension and thyroid disorder. There was surgical history of removal of fibroids 3 years back. Family history was not relevant. Appetite was normal, sleep wake cycle disturbed, bowel and bladder normal and no addictions were present. Menstrual History- Age of menarche-17 years, duration of menstruation period43 years, Flow and cycle length -6days and normal bleeding,Menopause-60 years.

Clinical Findings: After taking informed consent of the patient, the physical examination was performed. On General Examination patient was conscious, cooperative and well oriented with time, place and person and was comfortable in supine and sitting position. She was afebrile, pulse rate was 78 beats/min and respiratory rate was 20 breaths/min thoracoabdominal type. Patient examined in position. On Observation, pallor was present, Icterus was absent, there was no clubbing, cyanosis, oedema feet. On Inspection there was no deformity, no muscle wasting, site of incision-lower abdomen, typePfanniestiel(horizontal), Length of scar on inspectionaprrox.20cm with bandage.

On Palpation Tenderness of grade 1 was present, temperature was slightly raised and there was slight spasm. Systemic examination- the examination of respiratory system revealed respiratory rate of 20 breaths/min chest wall was bilaterally symmetrical, breath sound normally heard. Examination of nervous system revealed no neurological deficit. Examination of cardiovascular system reveals pulse rate of 78 beats/ min,all peripheral pulses was present and heart sounds were normally heard. Examination of musculoskeletal system revealed abnormal posture- shoulder bilaterally symmetrical, rounded shoulder, increased lumbar
lordosis,ASIS symmetrical ,no knee deformity and foot neutral. Timeline: She was operated on 24-10-19 and after 1 week before pre-operative physiotherapy was started and postoperatively continued for 6 weeks.

Diagnostic Assessment: The active lumbar spine rangeof-motion assessment of the patient, conducted in standing, was in all directions within usual functional limits. She described the hip pain as more superficial than deep. The patient displayed bilateral hip-active and passive range of motion that was within normal limits in all directions, but her familiar pain was actively and passively induced in all directions across the entire range of motion, even when performing end-range overpressure. A Thomas test was conducted and revealed a deficiency in the flexibility of the right muscle of the iliopsoas, creating her familiar pain.

Therapeutic Intervention: Our short term goals was to educate the patient, reduce pain, increase strength of lower abdominals, increase strength of pelvic floor muscles, improve bed mobility activities, improve respiratory efficiency, prevent respiratory complications as patient was under anaesthesia and our long term goals was to maintain strength of abdominal muscles, to maintain strength of pelvic floor muscles, to make the patient functionally independent, to prevent fall and weight bearing activities, and teaching home based exercise programs.Interventions were started preoperatively and continued until postoperative period.

Follow Up and Outcomes: Patient was again asked to give follow up after 6 weeks, again physical examination was performed but no complaints were seen and reported. She returned to her household work 7 weeks after surgery. At that time ,the functional recovery was completed, the outcome at the end of the rehabilitation period, 6 weeks after surgery was full ROM of hip and knee joints, patient rated $1 / 10$ on NPRS. And no complications were present postoperatively.

\section{DISCUSSION}

This case report indicates high potential of recovery following hysterectomy. At the end of rehabilitation patient was without complaints of pain at incision site and was comfortable in performing all the activities of daily living and was able to move independently. She was able to make fast progress. Her surgery and recovery proceeded without any complication. Hysterectomy is a surgical procedure that greatly affects the quality of the person being treated, decreases self-esteem and changes the quality of life (Internet source, 2020c). Physiotherapist should ensure that surgeons and nursing staff are fully informed of everything that a physiotherapist may do to the treatment of patients and should clarify the importance of physiotherapy (Internet source, 2020d). Clinically, patients became more optimistic and were able to lead an independent life in the ward as they were made to mobilize around the ward and taught stair climbing (Krishnan et al., 2016). 
Table 1. Detailed regimen of preoperative physiotherapy is explained below

\begin{tabular}{|c|c|c|}
\hline \multirow[t]{8}{*}{$\begin{array}{l}\text { Phase } \\
\text { Pre operative } \\
\text { physiotherapy } \\
\text { Phase } 1 \text { (1 week) }\end{array}$} & $\begin{array}{l}\text { Goal } \\
\text { Patient education }\end{array}$ & $\begin{array}{l}\text { Exercise } \\
\text { Education regarding the } \\
\text { route of surgery, prognosis, } \\
\text { post surgical complications, importance } \\
\text { of physiotherapy, advice about exercises }\end{array}$ \\
\hline & $\begin{array}{l}\text { To prevent } \\
\text { respiratory } \\
\text { complications }\end{array}$ & $\begin{array}{l}\text { Deep breathing exercises(10 reps) } \\
\text { active cycle of breathing technique } \\
\text { (ACBT), supported coughing. }\end{array}$ \\
\hline & $\begin{array}{l}\text { To prevent circulatory } \\
\text { complications such as deep } \\
\text { vein thrombosis and } \\
\text { pulmonary embolism. }\end{array}$ & $\begin{array}{l}\text { Antiembolic stockings, limb elevation. } \\
\text { Early ambulation, full-range } \\
\text { plantar-and dorsiflexion of } \\
\text { ankle to increase venous return } \\
\text { in the calves, active hip and knee } \\
\text { flexion and extension and weight } \\
\text { transference and pressure relief } \\
\text { to reduce stiffness and soreness } \\
\text { of legs and buttocks. } \\
\text { She was encouraged to sit in a } \\
\text { chair on first postoperative day } \\
\text { for a short time and was } \\
\text { mobilized fully on the second day. }\end{array}$ \\
\hline & $\begin{array}{l}\text { Bed mobility to achieve } \\
\text { independence in ADLs }\end{array}$ & $\begin{array}{c}\text { She was shown supported resting } \\
\text { positions such as half lying with a } \\
\text { pillow under the thighs and side } \\
\text { lying with pillows between the } \\
\text { knees under the lower abdomen. } \\
\text { She was taught how to move from } \\
\text { lying to sitting (vice versa) via side } \\
\text { lying, to minimize any increase } \\
\text { in intraabdominal pressure. } \\
\text { When moving up the bed, she } \\
\text { was encouraged to bend her } \\
\text { knees and use her thigh muscles, } \\
\text { by digging in with the heels and } \\
\text { straightening the legs. The upper limb } \\
\text { support the trunk and the she pushes } \\
\text { down with them at the same time } \\
\text { as the knees are straightened so that } \\
\text { the buttocks lift up off the bed and back towards the pillows. }\end{array}$ \\
\hline & $\begin{array}{l}\text { To increase strength of } \\
\text { pelvic floor muscles }\end{array}$ & $\begin{array}{l}\text { She was made aware of the muscles of } \\
\text { the pelvic floor by showing diagrams ,videos etc. } \\
\text { She was asked to contract the muscles } \\
\text { and hold the contraction as long as possible(30x3 reps). }\end{array}$ \\
\hline & $\begin{array}{l}\text { To increase the strength of } \\
\text { abdominal muscles. }\end{array}$ & $\begin{array}{l}\text { Pelvic tilting taught in crook lying. She was asked to retract } \\
\text { the abdominal muscles and hold the contraction as long as possible. }\end{array}$ \\
\hline & Posture and back care & $\begin{array}{l}\text { She was advised to adopt supported } \\
\text { positions, using appropriately placed pillows or lumbar rolls. }\end{array}$ \\
\hline & Wind pain & $\begin{array}{l}\text { Early ambulation, gentle abdominal muscle } \\
\text { exercises, abdominal massage. }\end{array}$ \\
\hline
\end{tabular}

In order to help bladder and bowel function and control, pelvic organ support, as well as other areas of health, optimum pelvic floor muscle function is known. It is also recognized that complications may be a function of pelvic surgery in some of the these regions.It is suggested that there will be a decrease in the long-term prevalence of bladder issues, bowel difficulties and impaired pelvic floor and abdominal muscles in post-surgery patients by resolving the requirements for good bladder and bowel function/control and organ support in the early post- 
surgery stage when tissue repair and scar formation are important ( Internet source, 2009).

The latest research does not seem to support the routine use during abdominal surgery of prophylactic respiratory physiotherapy (Pasquina et al., 2006). A number of studies on this aspect are reflected in global studies(Murray et al., 2019; 2020; Vos et al., 2020; Wang et al., 2019; Lozano et al., 2019). Some of the related studies were reported by Gadge et al. (2018), Marfani et al. (2019), Patwa et al. (2019) and Jindal et al. (2020). Ladke et. al. (2020) reported on complication of postlaparoscopic morcellation (Ladke et al., 2020). Gawri et al. (2019) conducted a comparative study of laparoscopic assisted vaginal hysterectomy vs non-descent vaginal hysterectomy(Gawri et al., 2019). Other related studies were reviewed (Sinha et al, 2020; Bais et al., 2020).

Table 2. Detailed regimen of post operative physiotherapy is explained below

\begin{tabular}{|c|c|c|}
\hline Phase & Goal & Exercise \\
\hline \multicolumn{3}{|l|}{$\begin{array}{l}\text { Post operative } \\
\text { physiotherapy } \\
\text { Phase } 1 \text { (1-2 week) }\end{array}$} \\
\hline & Patient education & $\begin{array}{l}\text { Education regarding the } \\
\text { prognosis, post surgical complications, } \\
\text { importance of physiotherapy, } \\
\text { advice about exercises }\end{array}$ \\
\hline & Positioning & $\begin{array}{l}\text { Regular sitting and shifting positions } \\
\text { can help promote airflow and } \\
\text { eliminate secretions. }\end{array}$ \\
\hline & $\begin{array}{c}\text { To reduce pain at } \\
\text { the site of incision } \\
\text { Posture and back care }\end{array}$ & $\begin{array}{c}\text { Analgesics, careful } \\
\text { handling and relaxation } \\
\text { She was encouraged to sit, stand } \\
\text { and walk 'tall', using the trans versusab dominis. } \\
\text { Pectorals stretch for rounded shoulders. } \\
\text { Pressure relief and air } \\
\text { mattress to prevent pressure sores }\end{array}$ \\
\hline & $\begin{array}{l}\text { Mobility to } \\
\text { increase independence }\end{array}$ & $\begin{array}{l}\text { Walking down the corridors or around her bed. } \\
\text { This progressed to marching on the } \\
\text { spot and heading to the chair from their bed. } \\
\text { This raises the volume of the lungs, } \\
\text { enhances breathing, helps to extract } \\
\text { secretions, decreases her hospital stay, } \\
\text { and makes it easier for her to remove secretions. }\end{array}$ \\
\hline & $\begin{array}{l}\text { To prevent } \\
\text { respiratory } \\
\text { complications }\end{array}$ & $\begin{array}{c}\text { Airway clearing methods, such } \\
\text { as deep breathing exercises, active } \\
\text { cycle of breathing techniques (ACBT) } \\
\text { and autogenic drainage (AD), } \\
\text { splinted cough by } \\
\text { assisting the incision site. }\end{array}$ \\
\hline & $\begin{array}{c}\text { To increase upper limb } \\
\text { mobility and } \\
\text { chest expansion }\end{array}$ & $\begin{array}{l}\text { Upper limb mobility exercises such } \\
\text { as arm raising, thoracic expansion } \\
\text { exercises. Incentive spirometer } \\
\text { for maintaining respiratory efficiency. }\end{array}$ \\
\hline & $\begin{array}{l}\text { To increase Pelvic } \\
\text { floor muscle strength }\end{array}$ & $\begin{array}{l}\text { She was made aware of the muscles } \\
\text { of the pelvic floor by showing } \\
\text { diagrams, videos etc. } \\
\text { She was asked to contract the muscles } \\
\text { and hold the contraction as } \\
\text { long as possible ( } 30 \times 3 \text { reps). }\end{array}$ \\
\hline & $\begin{array}{l}\text { To increase the strength } \\
\text { of abdominal muscles }\end{array}$ & $\begin{array}{l}\text { Pelvic tilting and knee rolling } \\
\text { exercises in crook lying commenced }\end{array}$ \\
\hline
\end{tabular}




\begin{tabular}{|c|c|c|}
\hline & & $\begin{array}{l}\text { as soon as pain allows. She was asked to } \\
\text { retract the abdominal muscles and hold } \\
\text { the contraction as long as possible. }\end{array}$ \\
\hline & Rest & $\begin{array}{l}\text { Too much activity will cause } \\
\text { tiredness which can delay recovery } \\
\text { so she was asked to take rest } \\
\text { and taught relaxation techniques. }\end{array}$ \\
\hline \multicolumn{3}{|l|}{ Phase 2 (2-4weeks) } \\
\hline & $\begin{array}{c}\text { Mobility to } \\
\text { increase independence }\end{array}$ & Gradual increase in ambulation distance. \\
\hline & $\begin{array}{c}\text { To prevent respiratory } \\
\text { complications }\end{array}$ & ACBT and deep breathing exercises. \\
\hline & $\begin{array}{l}\text { To increase Pelvic } \\
\text { floor muscle strength }\end{array}$ & $\begin{array}{l}\text { She was asked to contract the muscles } \\
\text { and hold the contraction as } \\
\text { long as possible(30x3 reps) }\end{array}$ \\
\hline & $\begin{array}{l}\text { To increase the strength } \\
\text { of abdominal muscles }\end{array}$ & $\begin{array}{l}\text { She was asked to retract the abdominal. } \\
\text { muscles and hold the } \\
\text { contraction as long as possible. }\end{array}$ \\
\hline \multirow[t]{2}{*}{ Phase 3(4-6weeks) } & $\begin{array}{l}\text { Mobility } \\
\text { To maintain Pelvic } \\
\text { floor muscle strength }\end{array}$ & $\begin{array}{l}\text { Stair climbing and all ADL initiated } \\
\text { Asked to perform exercises regularly and } \\
\text { ontract the muscles while coughing } \\
\text { cand sneezing (counter bracing) }\end{array}$ \\
\hline & $\begin{array}{l}\text { To maintain the strength } \\
\text { of abdominal muscles } \\
\text { Safe return to daily } \\
\text { activities and normal } \\
\text { function and home } \\
\text { exercise program }\end{array}$ & $\begin{array}{l}\text { Perform abdominal contractions } \\
\text { regularly and during ADL. } \\
\text { Written exercise regimen was } \\
\text { given to patient and advice to } \\
\text { avoid heavy lifting was given. } \\
\text { Advice regarding performing } \\
\text { pelvic and core strengthening } \\
\text { exercises was given. }\end{array}$ \\
\hline
\end{tabular}

\section{CONCLUSION}

The case report showed that physiotherapy treatment carried out immediately after gynecological surgery enhances the patients' quality of life and a planned exercise program helps the patient more than traditional management of physiotherapy and should be emphasized to all patients after gynecological surgery.For at least six weeks after surgery, it is necessary to proceed with gentle exercises. Ideally, for the rest of life, particularly the pelvic floor exercises, the patient should continue to do them. Patients should avoid all high-impact exercise until at least 12 weeks after surgery.

Author's Contribution: Author made her best contribution for the concept,assessment and evaluation, data analysis and interpretation of data.

\section{Conflict of Interest: None}

\section{Funding Support: None}

\section{REFERENCES}

Bais, A., Bawiskar, D., Naqvi, W.M. and Sahu, A., 2020. A case study on the impact of physiotherapy on unilateral foot drop after lumbar fusion and discectomy. Medical
Science, 24(103), pp.1773-1779.

Full Text PDF [Internet source, 2020b]. [cited 2020 Dec 6]. Available from: https://www.intechopen.com/ citation-pdf-url/51163

Gawri, D.J., Agrawal, D.M.,Waigi, R. 2019. A Comparative Study of Laparoscopic Assisted Vaginal Hysterectomy vs Nondescent Vaginal Hysterectomy for Benign Gynaecological Diseases.International Journal of Pharmaceutical Research, 11(4), pp.2018-21. https:// doi.org/10.31838/ijpr/2019.11.04.503.

Hysterectomy - Surgery - Womens Health - What We Treat - Physio.co.uk [Internet source, 2020a]. [cited 2020 Dec 6]. Available from: https://www.physio.co.uk/whatwe-treat/womens-health/surgery/hysterectomy.php Hysterectomy and Vaginal Repair [Internet source, 2016]. Hull University Teaching Hospitals NHS Trust. 2016 [cited 2020 Dec 6]. Available from: https://www. hey.nhs.uk/patient-leaflet/hysterectomy-vaginalrepair/

Jindal, R. and Swarnkar, M., 2020. Outcomes are Local: A Cross Sectional Patient Specific Study of Risk Factors for Surgical Site Infections in Major Abdominal Surgeries. Journal of Krishna Institute of Medical Sciences University, 9, pp.43-50. 
Karlsson, B., Granberg, S., Hellberg, P. and Wikland, M., 1994. Comparative study of transvaginal sonography and hysteroscopy for the detection of pathologic endometrial lesions in women with postmenopausal bleeding. Journal of ultrasound in medicine, 13(10), pp.757-762.

Latchoumi, T.P., Ezhilarasi, T.P. and Balamurugan, K., 2019. Bio-inspired weighed quantum particle swarm optimization and smooth support vector machine ensembles for identification of abnormalities in medical data. SN Applied Sciences, 1(10), pp.1-10.

Ladke, A.B., Palaskar, P.A. and Bhivsane, V.R., 2020. Parasitic Fibroid: Complication of Post-Laparoscopic Morcellation. The Journal of Obstetrics and Gynecology of India, pp.1-3.

Lozano, R., Fullman, N., Mumford, J.E., Knight, M., Barthelemy, C.M., Abbafati, C., Abbastabar, H., AbdAllah, F., Abdollahi, M., Abedi, A. and Abolhassani, H., 2020. Measuring universal health coverage based on an index of effective coverage of health services in 204 countries and territories, 1990-2019: a systematic analysis for the Global Burden of Disease Study 2019. The Lancet, 396(10258), pp.1250-1284.

Marfani, G., Phatak, S.V., Madurwar, K.A. and Samad, S., 2019. Role of sonoelastography in diagnosing endometrial lesions: Our initial experience. Journal of Datta Meghe Institute of Medical Sciences University, 14(1), p.31.

Murray, C.J., Abbafati, C., Abbas, K.M., Abbasi, M., Abbasi-Kangevari, M., Abd-Allah, F., Abdollahi, M., Abedi, P., Abedi, A., Abolhassani, H. and Aboyans, V., 2020. Five insights from the global burden of disease study 2019. The Lancet, 396(10258), pp.1135-1159.

Murray, C.J., Aravkin, A.Y., Zheng, P., Abbafati, C., Abbas, K.M., Abbasi-Kangevari, M., Abd-Allah, F., Abdelalim, A., Abdollahi, M., Abdollahpour, I. and Abegaz, K.H., 2020. Global burden of 87 risk factors in 204 countries and territories, 1990-2019: a systematic analysis for the Global Burden of Disease Study 2019. The Lancet, 396(10258), pp.1223-1249.

Pasquina, P., Tramer, M.R., Granier, J.M. and Walder, B., 2006. Respiratory physiotherapy to prevent pulmonary complications after abdominal surgery: a systematic review. Chest, 130(6), pp.1887-1899.

Patwa, P., Phatak, S., Pattabiraman, S. and Marfani, G., 2019. Ultrasound and color doppler features of transitional cell carcinoma of the endometrium with pathological correlation. Journal of Datta Meghe
Institute of Medical Sciences University, 14(4), p.429. Ponmathi, P., Krishnan, N.S. and Sivakumar, V.P.R., 2016. Effectiveness Of Physiotherapy Management Over Quality Of Life In Post Operative Gynaecological Patients. International Journal Of Physiotherapy, 3(5), pp.497-501.

Recover Right after Hysterectomy [Internet source, 2020b]. Exercise Right. 2017 [cited 2020 Dec 6]. Available from: https://exerciseright.com.au/recoverright-hysterectomy/

Sinha, S., Sinha, R.K., Phansopkar, P. and Chaudhary, S., 2020. Effect of psychomotor physiotherapy with individualized physiotherapy program on pain, kinesiophobia and functional outcome following Transforaminal Interbody Lumbar Fusion (TLIF): A case report. Medical Science, 24(106), pp.4091-4097.

Sullivan, K., Reeve, J., Boden, I. and Lane, R., 2016. Physiotherapy following emergency abdominal surgery. Actual Problems of Emergency Abdominal Surgery, p. 109.

Symptom experience in women after hysterectomy - PubMed [Internet source, 2020c]. [cited 2020 Dec 6]. Available from: https://pubmed.ncbi.nlm.nih. gov/11572527/

University of Melbourne. The Effect of a Physiotherapy Treatment Program on Pelvic Function Following Gynaecological Surgery [Internet source, 2009]. clinicaltrials.gov; 2009 Feb [cited 2020 Dec 3]. Report No.: NCT00222326. Available from: https://clinicaltrials. gov/ct2/show/NCT00222326

Vos, T., Lim, S.S., Abbafati, C., Abbas, K.M., Abbasi, M., Abbasifard, M., Abbasi-Kangevari, M., Abbastabar, H., Abd-Allah, F., Abdelalim, A. and Abdollahi, M., 2020. Global burden of 369 diseases and injuries in 204 countries and territories, 1990-2019: a systematic analysis for the Global Burden of Disease Study 2019. The Lancet, 396(10258), pp.1204-1222.

Wang, Haidong, Kaja M. Abbas, Mitra Abbasifard, Mohsen Abbasi-Kangevari, Hedayat Abbastabar, Foad Abd-Allah, Ahmed Abdelalim et al. "Global age-sexspecific fertility, mortality, healthy life expectancy (HALE), and population estimates in 204 countries and territories, 1950-2019: a comprehensive demographic analysis for the Global Burden of Disease Study 2019.” The Lancet 396, no. 10258 (2020): 1160-1203.

Women's Health - 1st Edition [Internet source, 2020d]. [cited 2020 Dec 6]. Available from: https://www.elsevier. com/books/womens-health/sapsford/978-0-70202209-8 